НАУКОВИЙ ВІСНИК

Eentific messenger of Lviv National University of

(2)

(x)

TIIII

СЕРя -слльсыкогосполен

Науковий вісник Дьвівського національного університету ветеринарної медицини та біотехнологій імені С.3. Гжицького. Серія: Сільськогосподарські науки

Scientific Messenger of Lviv National University of Veterinary Medicine and Biotechnologies. Series: Agricultural sciences

UDC 502.3:930.1

\title{
Climate vibrations and ecosystemogenesis of the Ukrainian Society from the Birth of Christ to the formation of the Grand Duchy of Lithuania
}

\author{
P. S. Hnativ ${ }^{1}$, V. V. Snitunskyj ${ }^{1}$, V. M. Polovyy ${ }^{2}$, B. V. Gutyj ${ }^{3}$, V. J. Ivaniuk ${ }^{1}$, N. I. Lahush ${ }^{1}$ \\ ${ }^{1}$ Lviv National Agrarian University, Lviv, Ukraine \\ ${ }^{2}$ Institute of Agriculture of Western Polissia NAAS, Rivne, Ukraine \\ ${ }^{3}$ Stepan Gzhytskyi National University of Veterinary Medicine and Biotechnologies Lviv, Ukraine
}

Article info

Received 17.02.2020

Received in revised form 16.03.2020

Accepted 17.03.2020

Lviv National Agrarian University, Great Vladimir Str., 1, Dubliany, Zhovkva district, L'viv region, 80381, Ukraine.

Tel.: +38-032-22-42-335

E-mail:pshnativ@ukr.net

Institute of Agriculture of Western Polissia NAAS, Rivnenska Str., 5

Rivne, 35325, Ukraine

Stepan Gzhytskyi National University of Veterinary Medicine and Biotechnologies Lviv, Pekarska Str., 50, Lviv, 79010, Ukraine.
Hnativ, P. S., Snitunskyj, V. V., Polovyy, V. M., Gutyj, B. V., Ivaniuk, V. J., \& Lahush, N. I. (2020). Climate vibrations and ecosystemogenesis of the Ukrainian Society from the Birth of Christ to the formation of the Grand Duchy of Lithuania Scientific Messenger of Lviv National University of Veterinary Medicine and Biotechnologies. Series: Agricultural sciences, 22(92), 99-107. doi: $10.32718 /$ nvlvet-a9217

Fluctuations in the climate of Eurasia during the Middle Holocene led to various adaptations of agriculture and livestock, which were engaged in the primitive ethnic groups in the current territory of Ukraine. Using the methods of paleogeography, paleoclimatology, paleobiology, the dynamics of landscape ecosystems are reconstructed and presented in the form of verbal and graphic models of the past dynamics. This allows us to understand the nature of agricultural sustainability, climatogenic transformation of landscapes and the peculiarities of the formation of the Ukrainian ethnic group in a dynamic natural environment. We show the decisive role of natural properties of local primary landscape ecosystems in the history of Ukrainian society from the time of the collapse of the Roman Empire to the beginning of the small ice age in Ukraine. The dynamics of the global and local climate (mesoclimate) is traced and analyzed and its connection and significant influence on the motivation of tribal movement in Central and Eastern Europe are shown. Migration waves, population outbreaks in some tribes, and the decline and assimilation of others are linked to the biotic, behavioral, and ultimately social and economic adaptation of peoples and the changing natural environment. The most effective and efficient adaptation is determined by the bioethological advantages of aboriginal (indigenous - those formed in the primary ecosystem) human tribal populations, prone to use their own ways of survival in local natural landscapes and often able to assimilate immigrant cultures. customs. According to our conclusions, based on the study of climate history and age dynamics of landscape ecosystems, the agricultural adaptability of primitive ethnic groups was the key to the survival and transformation of tribes into a nation during the Middle Holocene. The relatively stable tenthousand-year climatic period of the Holocene already had extremes of high temperatures in the Minoan (Trypillia period), Roman warm subperiods (the period of prosperity of the Russian state), which are not yet surpassed. Ending in the middle of the twentieth century. it passes into the Anthropocene, and the climate changes rapidly in the direction of warming. Without an in-depth paleoecological analysis of the dynamics of landscape and biome ecosystems, it will be impossible to develop rational ways to adapt the agrocomplex and environmentally safe nature management to the modern transformation of the Earth's climate and mesoclimate.

Key words: paleoecology, Holocene, ethnogenesis, climatic fluctuations.

\section{Коливання клімату й екосистемогенез українського соціуму від Різдва Христового до становлення Великого Князівства Литовського}

\author{
П. С. Гнатів ${ }^{1}$, В. В. Снітинський ${ }^{1}$, В. М. Польовий ${ }^{2}$, Б. В. Гутий ${ }^{3}$, В. Я. Іванюк ${ }^{1}$, Н. І. Лагуш ${ }^{1}$ \\ ${ }^{1}$ Львівський начіональний аграрний університет, м. Львів, Украйна
}


${ }^{2}$ Інститут сільського господарства Західного Полісся НААН, м. Рівне, Україна

${ }^{3}$ Львівський національний університет ветеринарної медицини та біотехнологій імені С. 3. Гжииького, м. Львів, Україна

Флуктуаиї клімату Свразї̈ упродовж середнього Голоцену спричиняли різнопланову адаптацію землеробства і скотарства, яким займалися первісні етноси на теперішніх теренах України. 3 використанням методів палеогеографії, палеокліматології, палеобіології реконструйовано й подано у формі вербальних і графічних моделей минулого динаміку ландшафтних екосистем. Це дозволяє зрозуміти природу сталості сільського господарства, кліматогенної трансформаиї ландшафтів та особливості формування українського етносу в динамічному природному середовищі. Нами показана визначальна роль природних властивостей місцевих первинних ландмафтних екосистем в історії становлення українського соиіуму від часів розпаду Римської Імперії до початку малого льодовикового періоду в Україні. Простежено й проаналізовано динаміку глобального та місцевого клімату (мезоклімату) й показано ї̈ зв'язок і вагомий вплив на мотивацію переміщення племен на теренах Центральної і Східної Свропи. Міграційні хвилі, спалахи популяцій одних племен $і$ занепад та асиміляція інших пов'язані з біотичною, поведінковою $і$ врешті-решт соціальною та господарською адаптацією народів і мінливим природним середовищем. Найефективніша і результативна адаптаиія визначається біоетологічними перевагами аборигенних (автохтонних - таких, щяо утворилися у первинній екосистемі) людських племінних популящій, схильних до використання своїх власних способів виживання у місцевих природних ландшафтах $і$ часто спроможних асимілювати імміграчійні хвилі працездатних прибульців прийнятного рівня культури $і$ звичаїв. За нашими висновками на підставі дослідження історії клімату й вікової динаміки ландшафтних екосистем - сільськогосподарська адаптивність первісних етносів була ключем до виживання і перетворення племен у нації упродовж середнього Голоцену. Відносно стабільний десятитисячолітній кліматичний період Голочен вже мав екстремуми високих температур у Мінойському (Трипільська доба), Римському теплих субперіодах (доба розквіту Руської Держави), які ще не перевершені. Закінчуючись у середині ХХ ст., він переходить в Антропоцен, а клімат стрімко змінюється у бік потепління. Без глибокого палеоекологічного аналізу динаміки ландиафтних $i$ біомних екосистем виробити раціональні шляхи адаптації агрокомплексу і безпечного для довкілля природокористування до сучасної трансформаиії клімату на Землі та мезоклімату регіонів буде неможливо.

Ключові слова: палеоекологія, Голоцен, етногенез, кліматичні флуктуації.

\section{Вступ}

Від кінця Плейстоцену в Центральній Європі розпочалося освоєння природних ресурсів людиною соціальною (Gnativ, 2015). Оскільки екопотенціал ландшафтних екосистем формується відповідно до місцевого мезоклімату (співвідношення тепла і вологи), життя племен і формування етносів від пізньоримської доби і надалі залежало головно від природних ресурсів і природних умов. На це вказує більшменш стала щільність людської популяції упродовж майже двох тисячоліть до початку індустріальної революції (Hnativ \& Snintynskyj, 2017). Особливі фізико-географічні умови території України сприяли імміграціям, осілості та злиттю різних етносів у місцевих ландшафтах, потужному розвитку землеробства, скотарства, матеріальної і духовної культури (Grygorenko \& Jesjunin, 2011).

Сучасна криза природокористування і нез'ясовані причини стрімкого прискорення змін клімату, які сукупно загрожують розбалансуванню природного довкілля, а згодом і середовища життя людини, спаду сільськогосподарського виробництва (Ukraina..., 2005; Schaller \& Weigel, 2007; Dan, 2010; Hausfather, 2016), росту соціальної напруги й конфліктів, аж до збройних включно, зумовлюють потребу дослідити ретроспективу антропотрансформації ландшафтів, еволюції взаємозалежності природних процесів i соціальних перетворень. Це потрібно для розроблення дієвих заходів у захисті довкілля (Fagan, 2008; Hnativ et al., 2012) і не відволікатиме громадськість порожніми політичними деклараціями, навіть на рівні ООН тощо, які здебільшого $є$ компромісними і приховують ïx фактичну політичну мету (Despite 20th..., 2010).

На основі реконструкції динаміки ландшафтних екосистем маємо за мету показати роль місцевих природних ресурсів і коливання кліматичних умов у поведінковій адаптації, виживанні й становленні українського соціуму від розпаду Другого Риму, упродовж розквіту й занепаду Руської Держави
(Київської Русі - за ідеологічним московським кліше), до встановлення кліматичного мінімуму температури повітря у Свразії в Голоцені.

\section{Матеріал і методи досліджень}

За методологію палеоекології використовуємо методи палеогеографії, палеокліматології, палеобіології, антропології, археології, історичної демографії й суспільної історії (Veklych, 1990; Harenberg, 1992; Jones et al., 1999; Arobba et al., 2004; Migowskia et al., 2006; Zaliznjak, 2008; Birks, 2008; Schönwiese, 2008; Fagan, 2008; Braconnot et al., 2012) для реконструювання у вербальних і графічних моделях екосистем минулого, щоби зрозуміти умови й чинники розвитку українського соціуму під впливом коливань клімату. Для цього аналізуємо особливості минулого природного довкілля, екопотенціал ландшафту як екосистеми, агробіорізноманіття. На основі збору даних про природні і середовищні ресурси ландшафтних екосистем (іхніх екопотенціалів (Hnativ et al., 2012; Hnativ \& Snintynskyj, 2017), аналізуємо їхнє походження, динаміку і майбутне, у т. ч. еволюцію соціуму, як його гармонійного компонента.

Для пояснення використаних положень та основних понять зазначимо, що екопотенціалом ландшафту (ландшафтної екосистеми) вважаємо сукупність речовинно-енергетичних ресурсів, властивостей і природних умов корінних для певної місцевості (нативних) екосистеми, які забезпечують іiі максимально можливі й самодостатні структурно-функціональні параметри (енергетичні, організаційні, біогеохімічні, водотрансформаційні, середовищні) (Hnativ \& Snintynskyj, 2017). Екопотенціал таких систем є максимальним обсягом корисних для людини як біотичної, так і соціальної, функцій (ресурсних, захисних, продукційних тощо). Вторинний екопотенціал екосистеми - це сукупність ії речовинно-енергетичних ресурсів і властивостей, сформованих під впливом антропізації (у т.ч. землеробства і скотарства), за якої 
формуються іiі поточні структурно-функціональні параметри і корисні функції. Повне використання екопотенціалу переважно руйнівне для ландшафту і зазвичай недосяжне, небажане, оскільки означає повне знищення екосистеми.

Рівень екопотенціалу помірної зони Свразії визначає гідротермічний коефіцієнт Селянінова (ГТК). ГТК - це показник температурно-вологісних ресурсів ландшафту, який вираховують за відношенням суми опадів у мм за період із середньодобовими температурами повітря понад $10^{\circ} \mathrm{C}$ до суми температур за той же час, зменшеним у 10 разів. Чим менший показник ГТК, тим сухіша місцевість. За гідротермічним режимом кліматичні області бувають: 1) аридні - сухі $(Г Т К<0,30)$ - поширена зріджена трав'яна і чагарникова рослинність пустельного i напівпустельного типу; 2) семіаридні - напівпосушливі (ГТК $=0,31$ $0,60)$ - пошир ена трав'яна i деревно-чагарникова рослинність степів, саван, твердолистяних субтропічних і сухих тропічних лісів; 3) семігумідні напіввологі $(\Gamma \mathrm{TK}=0,61-1,00)-$ поширені листопадні тропічні ліси, вологі савани, лісостепова рослинність помірного поясу; 4) гумідні - вологі (ГТК > 1,00) основні області поширення лісової рослинності. Ізолінія ГТК, взятого за одиницю, тепер проходить північним краєм Степу України (Hnativ et al., 2012). Екопотенціал охоплює продукцію рослинного покриву, тваринного світу, родючість грунтів, водні ресурси і гідромережу, теплові й вітроенергетичні ресурси ландшафту, у сучасну добу технічного розвитку - i людські, і рекреаційні.

Антропогенез (у розумінні виникнення й розвитку людини соціальної) вважаємо одним із основних результатів синергії еволюції ландшафту, клімату, біоти й людини біотичної, що триває i дотепер. Антропізація - це, за нашим розумінням, “олюднення", перетворення ландшафту: заселення, урізноманітнення засобами виробництва, господарське конструювання штучних екосистем для виживання, створення комфортного довкілля проживання й розвитку соціуму або завоювання силовими діями маргінальними номадичними соціумами (Hnativ \& Snintynskyj, 2017).

Як природне тло соціальних змін на теренах України використовуємо реконструкційну модель динаміки клімату за показником коливання приземної температури у північній півкулі від Різдва Христового (Р. Х.) до початку сталих метеорологічних спостережень, запропоновану Б. Фаганом (Fagan, 2008).

\section{Результати та їх обговорення}

Чергова хвиля погіршення клімату (похолодання й гумідизація), описана нами (Gnativ, 2015) від III ст. по P. X., що, за нашим припущенням, стало головною причиною кризи виробництва і суспільних потрясінь у Свразії. На тлі таких глобальних трансформацій природи простежуємо період занепаду Римської Імперії і вступ в епоху раннього феодалізму (Harenberg, 1992; Zaliznjak, 2008; Semenjuk, 2010).

\section{Кліматичні аномалії і Велике переселення народів}

Ще від початку вступу у Залізну добу кліматична ситуація в Свразії зумовила величезні міграційні потоки (Abashyna, 2003) - період Великого переселення народів. Воно тривало не лише 3 напівпустельних i степових зон Свразії, а й із Північної, Прибалтійської та Північно-східної Європи. Ці процеси згодом стали природним тлом формування і закріплення на тривалий період жорстокого суспільного ладу - середньовічного феодалізму.

Наступні хвилі сприятливих кліматичних змін (до 400-го року по Р. Х.) активізували життя місцевих племен - антів (сарматів - рабовласницьке виробництво), які, об'єднавшись зі східними кочовиками гунами, змели або асимілювали як північних прибульців, так і аборигенів на їхніх корінних землях (Harenberg, 1992; Zaliznjak, 2008; Chaplygina, 2009; Semenjuk, 2010).

Сармати (алани, роксоляни й ін.), що жили на північному узбережжі Чорного та Азовського моря (між Дністром та Доном від III ст. до Р. Х. до III ст. по Р. Х., за культурою близькі до скіфів. Займалися вони кочовим скотарством. Важливо зазначити, що скіфські й сарматські племена були кочовиками або нома-

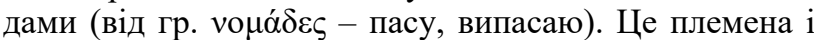
групи, що з економічних, традиційно-культурних або інших причин не мають постійного нерухомого майна (житла, укріплень, фортець). Вони переміщуються 3 одного місця на інше залежно від ресурсів місцевості, а конкретніше - від екопотенцалу трав'яних екосистем степів і напівпустель (навіть тундри), який своєю чергою формується під дією гідротермічного коефіцієнту зональних екосистем. Ці соціуми не були безслідно знищені, оскільки були частково асимільовані осілими протослов'янами-землеробами.

Упродовж I-III ст. по Р. Х. на ДністровськоКарпатських землях запанували сармати, а упродовж IV ст. розвинулася Черняхівська культура праслов'янських племен склавинів та антів. Проте вже від III ст. у північне Причорномор'я з північного заходу вторглися готи, вандали, гепіди й ін., гнані з рідних просторів істотним похолоданням. Вони витіснили частину сарматів на схід, зруйнували міста аж до р. Дону, захопили Крим. Уцілів лише Херсонес.

Готи сформувалися в Скандинавії, коли там прогресував м'який і теплий (Osborn, 2004) клімат (рис. 1 - 1). Їх прабатьківщиною вважають південь сучасної Швеції та острів Готланд.

3 погіршенням мезоклімату ландшафту у бік похолодання (рис. 1 - 2), готські племена мігрували звідти спочатку в Померанію (тепер північна Польща), потім розділилися і пішли на південь - у тепліший клімат. 230 року по Р. Х. у Причорномор'ї виникає держава Рейхготланд. Найбільшої могутності вона досягла за часів правління готського вождя Германаріха (332375 pр.) та його наступника Вінітарія, коли у південних степах теперішньої України після тривалого потепління (рис. 1 - 3) встановився вологий та прохолодний клімат (рис. $1-4)$, що був комфортнішим для цього північного етносу, ніж сухий степовий. 


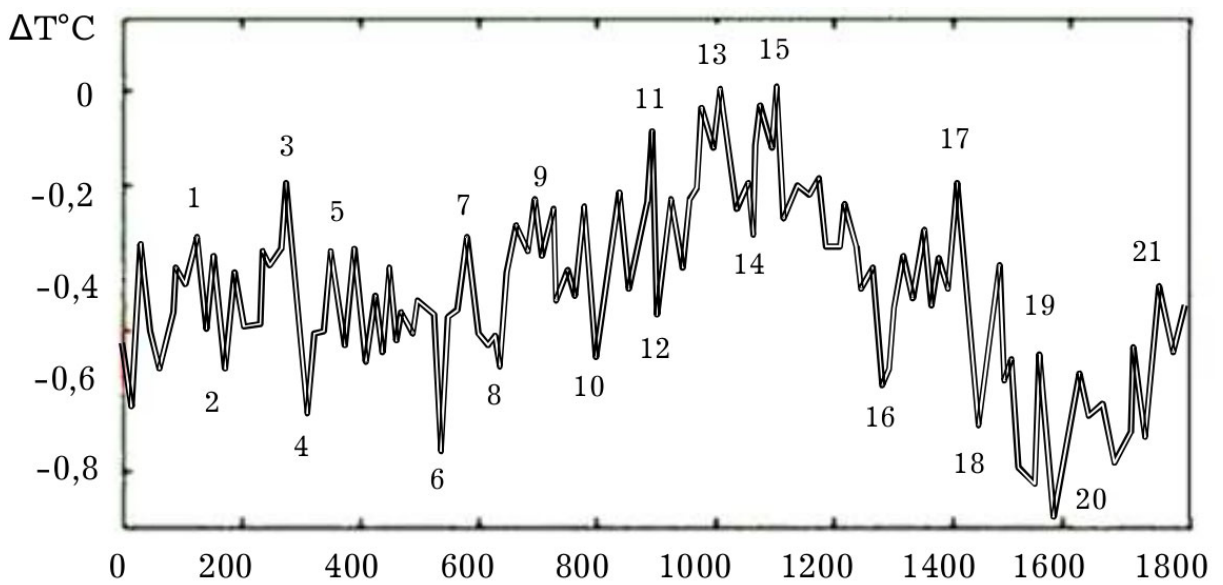

Рис. 1. Динаміка коливання температури приземної атмосфери $\left(\mathrm{y}^{\circ} \mathrm{C}\right)$ в північній півкулі стосовно кліматичної норми Голоцену $\left(\Delta \mathrm{T}^{\circ} \mathrm{C}=0\right)$ за реконструкцією Б. Фагана й інших авторів (Fagan, 2008; Casey, 2008) від Р. Х. до початку сталих метеорологічних спостережень (непарні цифри - екстремуми потепління, парні - похолодання)

Готам доводилося вести постійні війни з аборигенами - праслов'янами (антами), які розвивалися. 375 року Вінітарій підкорив антів і знищивши їхніх вождів. Але незадовго готів розгромили й асимілювали гуни, що уклали союз з антами і вторглися у Південно-Східну Європу зі сходу. Як і сармати, фракійські та слов'янські племена змішалися й асимілювалися або частково були витіснені готами й y IV ст. - гунами. Міграція гунів збігається зі значним похолоданням (рис. 1 - 4) у Свропі, а це зробило вкрай некомфортними умови проживання кочовиків у східноєвропейських і азійських степах, які зазнавали впливів сибірських антициклонів.

\section{Середньовічне потепління і Руська Держава}

$\mathrm{У}$ найхолодніші роки досередньовічного періоду першого тисячоліття після Р. Х., а саме 455 р., Рим розгромили гнані 3 півночі холодами вандали. 476 - рік позбавлення влади Ромула Августула, вважається "офіційною” датою падіння Імперії.

VI і початок VII ст. вирізняються зниженням середньорічної температури, гумідизацією клімату півдня України (рис. 1 - 6) і спалахом у цей час популяцій слов'янських племен. Це стимулювало їх масово розселятися південніше - за Дунай на Балкани, де вони, використовуючи гористу місцевість, достаток кам'яного матеріалу для укріплень та гірські річки для облаштування млинів, пристосувалися ефективно використовувати великий екопотенціал ландшафтних екосистем (Humilov, 1968; Gnativ, 2015), підтримувати виробництво матеріальних благ, боронитися від ворогів. Тут вони закріпилися й збільшувалися чисельно на таких же родючих землях долин річок, які були поширені у степовій Україні, коли там встановлювався гідротермічний коефіцієнт, що дорівнює одиниці.

562 р. на нижньому Дунаї з'являються вже аварські племена, а VII ст. вирізняється поступовою аридизацією клімату, коли із найвищою середньою температурою був кінець VI ст. (рис. 1 - 7). У цей час найпотужніше збільшується популяція слов'янських племен на усій теперішній території України й Білорусії. Від VI ст. на півдні теперішньої України повністю запанували напівпустельні племена аварів, або вархонітів, що становили залишки тюркомовного етносу, який жив у Приараллі, розбитого іншими ворожими номадами. Частина аварів мігрувала на захід, а частина - в пустелю Гобі. Аварський Каганат був поліетнічною державою, а в кінці IX ст. він зник під натиском угрів.

Приблизно у VII-VIII ст. по Р. Х. потужні й агресивні племена угрів (автохтонне населенням межиріччя Оки й Волги) під тиском похолодання й гумідизації ландшафту, внаслідок чого сталося залісення природним шляхом середньої смуги Східноєвропейської рівнини, перекочували 3 рідних місць, розселилися між ріками Доном і Дніпром й утворили союз із племенами іудейського Хазарського каганату (рис. $1-10)$. Хазари від кочового скотарства i військових грабунків сусідніх племен поступово переходили до землеробства й особливо - торгівлі. Осілим центром Хазарії був теперішній Дагестан, де хазари зайнялися навіть виноградарством. До IX ст. завдяки гумідизації клімату та під впливом хазар Крим, Тамань, пониззя Кубані й Дону перейшли від кочівлі до обробітку землі, оскільки обсяги опадів створювали запаси вологи в грунті, достатні для вирощування культур.

На рубежі VIII-IX ст. по Р. Х. на основі Полянського князівства 3 центром у Києві утворюється держава Русь - Руська Держава (а не Київська Русь, як її назвали через три століття після зникнення творці привабливої історії Московії (теперішньої Росії). Х ст. ознаменувалося входженням до ii складу земель між Дністром і Карпатами та включенням тиверців і хорватів до складу давньоруської народності.

Приблизно від 650 р. клімат північної півкулі від холодного й сирого стрімко змінювався до теплішого упродовж майже 100 років. Це, безумовно, сприяло підвищенню продуктивності займаних слов'янамиземлеробами угідь, росту продуктивності землеробської праці і збільшенню як свійського поголів'я, так і популяцій диких тварин, становленню та зміцненню давньоруської держави.

За умов сприятливого клімату (рис. 1 - 11) Руський князь Олег Віщий (882-912рр.) численними походами приєднав племена полян, древлян, сіверян, радимичів, а загалом влада Києва поширилася на словен, кривичів, хорватів, уличів, фіно-угорські племена, чудь, мерю й ін. 
Натомість у кочовиків головне завдання - не виробляти продукцію, продовольство й торгувати ними, а вирощувати коней для пересування й завоювання територій і прогодувати воїнів. Для цього їм потрібний сталий екопотенціал ландшафтних екосистем степів і напівпустель як джерело корму для тварин, а від тварин - їжа. Жодних запасів, про які дбає землероб, у кочовиків бути не може, окрім того, що потрібно на період від грабунку до грабунку. Тому вони повністю залежні від клімату й родючості пасовищ для тварин. Хлібороб же за найгірших погодних умов може скористатися запасами продовольства і пережити нетривалі лихоліття. 3 умовного гектара землі за найгіршої, примітивної форми організації землекористування чи несприятливої погоди хлібороб може зібрати 600 кг зерна. На чорноземах - це легко зробити, маючи любов до праці й елементарні навички. Якщо залишати на сівбу 200 кг, то запасом приблизно 400 кг зерна (по кілограму на добу) можна прогодувати сім'ю до нового врожаю, натомість отару овець чи табун коней - ні.

Саме 890 року, у пік потепління клімату в Свразії (Preiser-Kapeller, 2013(a); 2013(b); 2014 (рис. 1 - 9), кочові печеніги, які переміщалися зі східних пересохлих степів, їхні союзники - осілі русичі-землероби і дунайські болгари витіснили племена кочових угрів на захід - на територію між Дністром і дельтою Дунаю. Проте 894 р. угри за допомоги візантійського імператора Лева VI розбили військо болгарського царя Сімеона, а частина їх переселилася в район Переславля в Прикарпаття. Дорогою до Карпат угри розоряли, убивали й полонили русичів для продажу в рабство до Візантії. Цар Сімеон 3 нанятими печенігами 897 р. напав і знищив поселення угрів у північній Бессарабії i на Поділлі. Повернувшись із набігів, військо угрів зі страху покинуло ці землі. Ще 898 р. угри грабували околиці багатого Києва, а згодом переселилися на захід - у Прикарпаття - і перейшли Карпати. До них тоді приєдналися залишки хазарських кочовиків. Тодішній холодний і сирий клімат стимулював важкий перехід через потужні у той час дрімучі вологі ліси Карпат (рис. 1 - 12). Прикарпаття тоді було украй несприятливим для життя степовиків.

Територія Поділля на межі першого і другого тисячоліть по Р. Х. була освоєна племенами білих хорватів, дулібів, тиверців тощо і була під владою Києва. На Любецькому з’їзді 1097 р. iii передано Ростиславичам, правнукам Ярослава Мудрого, а вже за поділу Галичини між Ростиславичами вона припала князю Василькові, що мав свою столицю в Теребовлі. Окреме його князівство не існувало довго, бо по загибелі Василька 1124 р. воно було приєднано до Галицького князівства, яке за Ярослава Осьмомисла (11531187 рр.) поширило свою владу до Дунаю. Ріка Дністер, як південна окраїна території Руси-України, стала головною водною артерією торгівлі Галичини 3 Візантією.

Отже, зміни клімату, голод та організовані й розвинуті осілі племена автохтонних землеробів витіснили дикі кочові племена угрів (мадярів) із регіону вологого північного Причорномор'я у малозаселену семігумідну на той час Тисо-Дунайську низину, змусили прийняти осілий спосіб життя та перейти від грабунків і поборів до заняття власним виробництвом матеріальних благ.
Інші відомі кочовики доби раннього Середньовіччя на території України, які повністю залежали від екопотенціалу українського Степу i виживали пограбуваннями осілих сусідів: печеніги, половці, чорні клобуки, монголи, кримські татари, ногайці.

Завдяки найвищим у північній півкулі середньорічним температурам за весь період від Різдва Христового від початку XI ст. встановися найтепліший клімат. Степи й напівпустелі “вигоряли”, і навіть лісостепова зона зазнавала численних посух. У цей час історичні документи фіксують сильні посухи 994, 1042 і 1092 років. Особливо виокремлений 1092 рік (рис. 1 - 13 і 15), коли, як писали літописці “...висохли навіть болота і горіла земля” (вочевидь, це було горіння торфу). Саме у цей теплий і сухий кліматичний період у Києві правив Ярослав I Мудрий (1019-1054 рр.). В Суздалі за цих сприятливих умов наростала могутність місцевих племен, що становили навіть більшу загрозу для Києва, ніж кочові половці. Поступово сила їхніх ударів наростала, а кліматичні умови для степовиків істотно погіршувалися. Тому 1111 року зусиллями всіх князів виснажені голодом і посухами (рис. 1 - 15) половці були остаточно розгромлені.

Учені доводять, що основу господарства Руської Держави у надзвичайно сприятливих за ГТК умовах (період від 9 до 13 потепління - рис. 2) становило землеробство. Цієї думки дотримувалися М. Грушевський, Д.Багалій та Я. Пастернак. Вони вважають, що слов'яни традиційно були землеробами (Encyclopedia..., 1949). Підтвердженням цієї гіпотези $\epsilon$ часті згадки про землеробську діяльність на Русі у літописах, хліборобська орієнтованість календаря й міфології давніх слов'ян i, що найпереконливіше, археологічні знахідки. Сучасні розкопки виявили, що від Х ст. в Україні користувалися залізним лемішем і що тут, як і в Західній Свропі, мала поширення прогресивна у той час дво- і трипільна система сівозміни (за якою половина або третина оранки залишалася незасіяною (“під паром”). У культурі була переважно пшениця, овес, жито і ячмінь. Селяни на Русі вирощували худобу й волів, забезпечували себе м'ясом і молоком, шкірою для одягу, обладунків та взуття. Також традиційним було розведення коней, свиней, овець, гусей, курей і голубів. Використання волів сприяло продуктивності землеробства. Зауважимо, що упродовж Середньовічного теплого періоду (X-XIII ст.) на теренах Руської Держави, як і в Свропі загалом тривав демографічний вибух, пік якого встановився $1300 \mathrm{p}$.

Проте після тривалих княжих міжусобиць Київ уперше в результаті змови 1169 року був узятий штурмом і розграбований володимиро-суздальським володарем Андрієм Боголюбським. Столиця Руської Держави тоді мала 400 церков і була багатшим містом, ніж тодішні Лондон чи Париж. Саме цими роками завершується Середньовічний теплий період, розпочинається зниження середньорічної температури в Євразії й погіршення клімату. 1169 рік, ознаменований викраденням з Вишгородського монастиря (під Києвом) чудотворного образу Божої Матері, раніше освяченого у столиці Візантії - Царгороді, історики вважають роком народження Московії. Розбагатілі грабунками, гібридизовані угро-фінські й тюркські племена, нащадки північних канібалів, 3 
агресивністю лісових хижаків, гнані з півночі холодом і страхом голоду (рис. 1 - 16), з великою охотою нападали на розвинутіші, але політично немічні південні держави.

\section{Початок Малого льодовикового періоду $i$ Золота Орда}

Від ХІ до початку XII ст. численні дрібні тюркські племена, монголи, узбеки, казахи й ін. в умовах жорстких посух, браку кормів для тварин кочували у прикордонних землях Китаю і всю силу й енергію витрачали на боротьбу з голодом, на міжплемінні й родові війни за бідні ресурсами кормів степові й напівпустельні пасовища. Номади природно харчувалися виключно м'ясною їжею, урізноманітнюючи іiі кумисом, а така дієта є метаболічною основою природної агресії. За поступової гумідизації степів і напівпустель 1206 р. наймогутніші групи племен обрали собі вождя, дали йому ім'я Чингісхан і всі потрібні повноваження - як хану над ханами. Він швидко об'єднав роди, що ворогували, та змусив їх визнати свою абсолютну владу.
На тлі столітньої стрімкої гумідизації (див. рис. 1 від 15 до 16) (рис. 2) у минулому сухих і бідних рослинністю степових i напівпустельних ландшафтів (рис. 3), потужного росту біопродуктивності трав'яних екосистем і приросту популяцій диких коней, сайгаків, сибірських козуль тощо наступними кроками Чингізхана стали спрямування об'єднаної військової сили й агресії племен проти сусідніх осілих цивілізацій. Так, завдяки винятково сприятливим для кочових племен природним умовам і зрослим ресурсам, у т. ч. людським, утворилася унікальна в історії людства номадична супердержава - Золота Орда.

Уже 1237 p. на кордонах Русі 3'явилося різноплемінне, але переважно монголо-татарське військо на чолі 3 ханом Бату (Батиєм) - синьооким і русявим (як його зображали древні художники в літописах) онуком Чингісхана. Кочовики спочатку зруйнували міста Рязань, Суздаль і Володимир, а 1240 р. дійшли до Києва. Воєвода Дмитро, посланець Данила Галицького, очолив оборону від нападників. Облога міста була тривалою й жорстокою. На початку грудня 1240 р. Київ упав під ударами кочовиків, а військова міць Золотої Орди ще більше зростала.

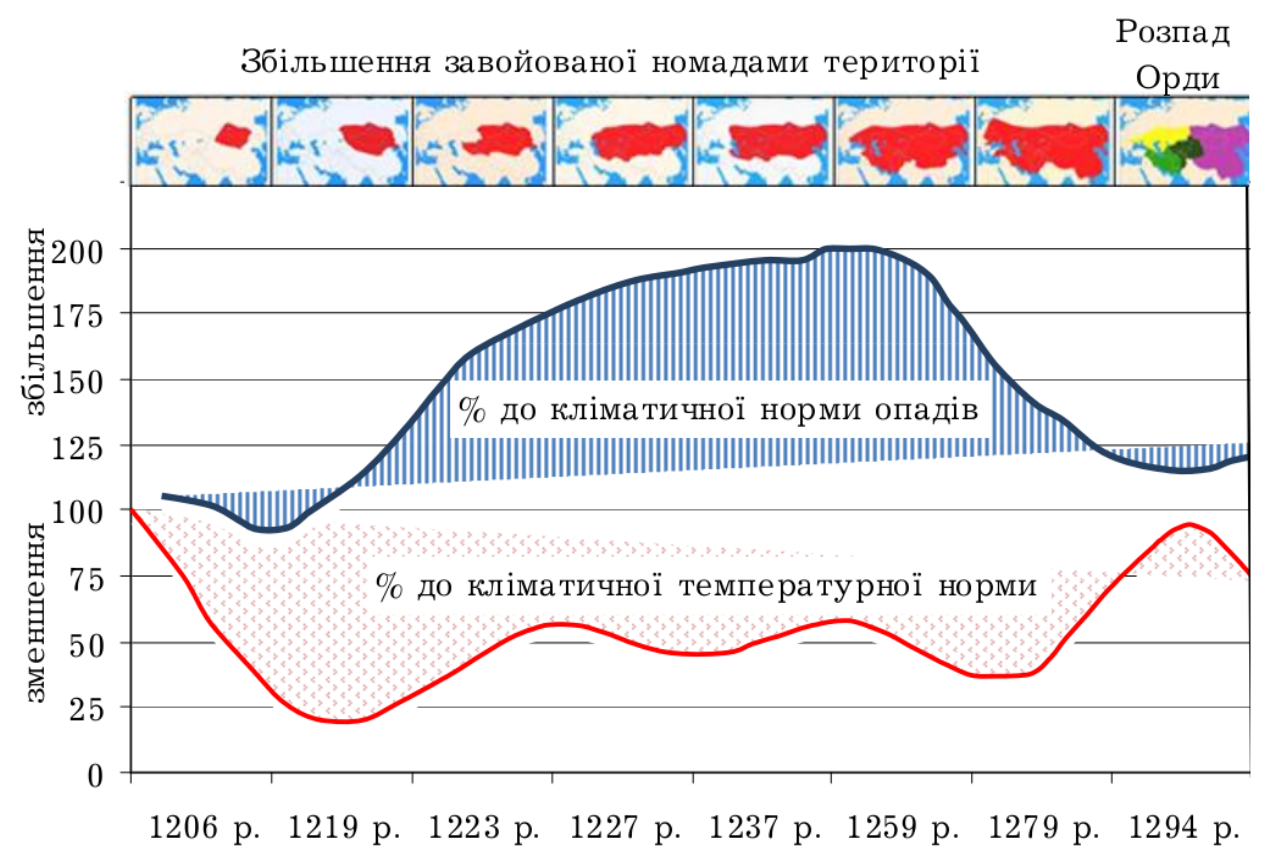

Рис. 2. Схема динаміки кліматичних змін (за Moberg et al, 2005) і території перманентного грабунку васальних володінь Золотої Орди у період збільшення популяції кочовиків і коней та зростання її військової потужності.

Від 1211 р. кочовики почали грабувати бурятів, якутів, киргизів, уйгурів. Від 1217 року вони вторглися у Північний Китай, 1219-1221 рр. - у Центральну Азію, роком пізніше - у Закавказзя, наступного року завоювали половецькі степи, 1236 р. знищили Волзьку Булгарію. Від 1237 р. розпочалися систематичні набіги на Руські землі, а від 1241-1242 рр. кочовики здійснювали спроби пограбувати й підкорити територію нинішніх Західної України, Польщі, Угорщини й Чехії. Галицько-Волинський Князь Данило, що приєднав Київ до своєї держави, змушений був просити від Золотої Орди (1259р.) “ярлик” (грамоту на князівство). 


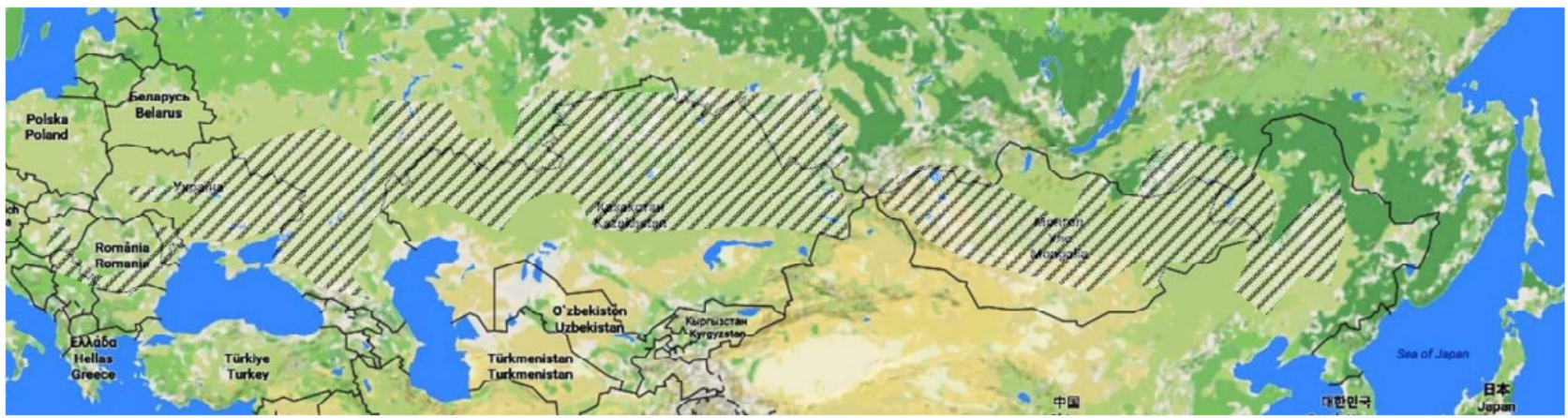

Рис. 3. Поширення Степу у Свразії.

У добу найбільшої потужності Золотої Орди 12571258 рр. в атмосферу Землі потрапила велика кількість вулканічних викидів, встановився найвищий рівень вмісту сірки - приблизно за розрахунками (Oppenheimer et al., 2011) 64 Мт, а також утворених від вулканічної активності сульфатних аерозолів 258 Тг. Лише 529 року по Р. Х. обсяг атмосферної сірки сягав приблизно 16 Мт і 1452 року 33 Мт. Такі аномально великі викиди вулканів, вірогідно, вплинули на атмосферні процеси і зумовили істотні кліматичні зміни, що спричинили пришвидшені темпи аридизації ландшафтів Євразії у цей період геологічної історії.

До цього часу кліматичні зміни “створили" оптимальні умови для розквіту Євразійського номадичного соціуму. Проте вони ж їх і “знищили”, надаючи можливість зростати й поширюватися іншому соціуму, що виник унаслідок злиття генетичних пулів тюркських та угро-фінських племен. Від моменту виникнення поселення Моква (згодом Москва) й розростання ординського московського улуса його європейські мандрівні посли і літописці називали Московією (Моксєллю за Г. де Рубруком (The Journal..., 2014).

Якими були зміни клімату в напрямку погіршення екопотенціалу степових i напівпустельних ландшафтів, свідчить рисунок 1 (точки 16, 18 і 20). Стрімке похолодання, що чергувалося 3 періодами потепління й посух, загалом зробили умови життя кочовиків нестерпними, хвороби й мор - перманентними. Окрім того, продуктивність рослинного покриву ландшафтів (Dan, 2010) у “володіннях" номадів почала стрімко зменшуватися й вони уже не могли утримати величезну кількість коней та інших тварин.

В осілих соціумів Східної і Центральної Європи на перший план вийшла перевага стаціонарного дерев'яного, навіть напівукопаного в землю, а у кращих випадках - кам'яного житла. На тлі таких природних змін нездатність номадичних етносів до культурноосвітнього поступу, удосконалення техніки й озброєння, як у європейських народів, до яких належить протоукраїнська соціальна спільнота, спричинила їхне стрімке відставання у розвитку і зумовила втрату військової могутності. За виняткового збігу природних сукцесій та суспільних трансформацій у Євразії Золота Орда до кінця ХІІІ ст. розпалася на дрібні ханства, а в Китаї заснована внуком Чингісхана Хубілаєм династія Юань.

\section{Малий льодовиковий період, Московія $і$ Украйна}

На відміну від кочовиків, які можуть переміщуватися за невідповідних кліматичних умов, сільськогосподарські цивілізації $є$ залежними від клімату, що позначається на врожайності угідь (Schaller \& Weigel, 2007). Проте за оптимальних кліматичних властивостей ландшафту і зрослого екопотенціалу рільних земель осілі соціуми мають такі переваги, які вони змогли використати для нарощування військової потужності.

Християнізовані грецькими й давньоруськими місіонерами, московіти кінця XVI - початку XVII ст. асимілювали західноазійську тюрко-монгольську еліту, перейняли від кочовиків агресивність, вождівський устрій держави і кастову структуру громад. Від розквітлої під ординським протекторатом православної церкви московіти прийняли “найцінніші” для абсолютної монархії релігійні принципи “...непротивления злу насилием...” та “...царь наместник Бога в миру”. Московія на той час досягла економічного розвитку рівня XIII-XIV ст. у Центральній Європі (Gucalo, 1996). За відсутності надійних сухопутних сполучень і від замерзання річок торгівля була дуже кволою, але відсутність доріг, непрохідні болота й залісення раніше степових ландшафтів ускладнили функції ханських баскаків та екзополітарне (зовнішне) управління улусами. Водночас осілого війська кочовики ніде не залишали.

Зростання продуктивних сил в сільському господарстві та ремеслі 3 використання екопотенціалу ландшафту спричинили розширення торгових зв'язків московитів 3 осілими Європейськими цивілізаціями. Сприятливі попередні екоумови спричинили ріст соціо-економічної потужності Московії як улуса 3олотої Орди. Натомість наступне вагоме погіршення кліматичних умов і депресивні тенденції у соціумі погіршили ситуацію в Золотій Орді. Ослаблена від XV ст. кліматичними змінами (рис. 1 - 18 і 20) i соціальними потрясіннями, номадична імперія прямувала до розпаду, а з появою мусульманської держави Тамерлана (1370-1405 рр.), який теж багато зробив для іiі руйнування (похід 1395 року), він пришвидшився.

Упродовж XV ст. відділилися окремі ханства: Казанське, Астраханське, Сибірське, Кримське. Найактивніший опір експансії московитів чинили Сибірське ханство і низка племінних союзів (наприклад, Хант), кочовики на кордоні з Китаєм, у Забайкаллі і на півдні Далекого Сходу. Натомість Кримське ханство династії Гераїв, проголосивши свою незалежність, уже 1475 р. прийняло протекторат Османської Імперії. 
Коли 1340 р. вимерла династія Романовичів, польський король Казимир Великий захопив Львів. Лише 1349 р., домовившись із татарами, які визнали його “паном руської землі”, він заволодів Галичиною і землями до Теребовлі включно.

Водночас князь Ольгерд - очільник Великого Князівства Литовського (яке було на політичній арені Східної Свропи 559 р. - від 1236 до 1795 року), приєднав більшу частину земель Русі: частину Смоленщини, Київщину, Переяславщину, ЧерніговоСіверщину, здійснив успішний похід проти ординців у Південній Україні, розбив татарське військо на Синіх Водах (1362 р.), у союзі з Тверським князівством воював із ординською Московією (13681372 рр.). Врешті-решт князь Ольгерд зайняв Поділля (офіційно в документах уперше так назване 1395 р. The Tchortkiv District, 1974). Тоді, за аномального потепління клімату (рис. 1 - 17), у Подільському краї були розбудовані міста 3 центром у теперішньому м. Кам'янці-Подільському. На західному Поділлі були споруджені замки в Червоногороді (с. Нирків) і в Скалі-Подільській над Збручем.

Початок XV ст. знаменується переселенням польської шляхти на Поділля 3 прохолодного клімату, який погіршувався у той період (рис. $1-18$ ), із бідних i болотистих підзолистих грунтів на родючі чорноземи. Католицьке єпископство заволодівало великими площами українських земель, що простиралися головно на західному боці Збруча (Устя “єпископське", Горошова, Михалків, Іване-Пусте, Залісся, Срмаківка (Гермаківка), Нівра, Новосілка "єпископська"; на схід від Збруча: Шестинці, Чорнокозинці). Польськокатолицька влада від 1435 р. усю землю відносно теплих i вологих українських територій віддала шляхті і прикріпила до неї селян, для яких залишала мізерні наділи.

На завершення зауважимо, що в цей період геологічної історії Голоцену встановився кліматичний мінімум температури приземного повітря у Свразії (рис. 1 - 20). Проте на самому початку XVII ст. унаслідок спалаху вулканічної активності (вулкан Гуанапутіна - 1600 р.) науковцями виявлена велика кількість сірки в компонентах екосистем та аерозолів сірки в повітрі. Це свідчить про істотне загальне забруднення атмосфери (Osborn, 2004; Oppenheimer et al., 2011). Цього року зафіксована важлива віха в геологічній історії Голоцену: започаткувалася стала тенденція зміни клімату в бік потепління, що триває дотепер.

\section{Висновки}

На підставі дослідження історії клімату й вікової динаміки ландшафтних екосистем підсумовуємо, що сільськогосподарська адаптивність первісних етносів була ключем до виживання і перетворення племен у нації упродовж середнього Голоцену.

Загалом Голоцен - це відносно стабільний десятитисячолітній кліматичний період, адже ще не перевершено екстремуми його температур у Мінойському (Трипільська доба), Римському теплих субперіодах (Briffa \& Osborn, 1999; Arobba et al., 2004; Schönwiese, 2008) i X-XIII ст. - доби розквіту Руської Держави.

Голоцен, закінчуючись у середині ХХ ст., переходить в антропоцен, а клімат у бік потепління змінюється настільки стрімко, що людство переживатиме великі трансформації. Попереду - температурні екстремуми, посухи, сильні шторми, підвищення рівня і підкиснення океану, інші зміни. Як будувати сільськогосподарську діяльність і природокористування, щоб протистояти майбутнім викликам - питання надзвичайно актуальне. Важливо передбачати подальшу можливу дегресію сільського господарства в аридних біомах і брати до уваги досвід ведення ефективного землеробства, баштанництва й садівництва в екстремальних умовах, що 3 давніх часів практикували в Україні.

Без глибокого палеоекологічного аналізу динаміки ландшафтних і біомних екосистем і за марксистського історіографічного підходу до аналізу суспільних процесів виробити раціональні шляхи адаптації агрокомплексу і безпечного для довкілля природокористування до сучасної трансформації клімату на Землі та мезоклімату регіонів неможливо.

\section{References}

Arobba, D., Boscato, P., Boschian, G., Falgueres, C., Fasani, L., Peretto, C., Sala, B., Hohenstein, U. T., \& Tozzi, C. (2004). Paleoenvironmental Analysis. Coll. Antropol., 28(1), 5-21. http://www.museoarcheologicodelfinale.it/ pdf/arobba/2004_palaeoenvironmentalanalysis.pdf.

Birks, H. J. B. (2008). Paleoecology. Encyclopedia of ecology. Amsterdam: Elsevier. Fath, 2623-2634. doi: 10.1016/B978-008045405-4.00525-5.

Braconnot, P., Harrison, S. P., Kageyama, M., Bartlein, P. J., Masson-Delmotte, V., Abe-Ouchi, A., OttoBliesner, B., \& Zhao, Y. (2012). Evaluation of climate models using palaeoclimatic data. Nature Clim. Change, 2, 417-424. doi: 10.1038/nclimate1456.

Briffa, K. R., \& Osborn, T. J., (1999). Seeing the wood from the trees. Science, 284(5416), 926-927. doi: $10.1126 /$ science.284.5416.926.

Chaplygina, N. A. (2009). Naselenie DnestrovskoKarpatskix zemel i Ryma v I-III veke nashey ery [The population of the Dniester-Carpathian lands and the Rome I-III century. BC] (in Russian).

Casey, T. (2008). Climate Change Catastrophes in Critical Thinking. Consulting Geologist. http://climate.geologist-1011.net.

Dan, A. (2010). The lessons of climate history: implications for post-carbon agriculture. Energy Bulletin. http://www.resilience.org/stories/2010-05-17/lessonsclimate-history-implications-post-carbon-agriculture.

Despite 20th... (2010). Despite 20th Century Minor Warming, Ice Cores Indicate Earth Is Still Cooling Since The Warming of Minoan Period. Retrieved from: http://www.c3headlines.com/2010/03/despite20th-century-minor-warming-ice-cores-indicate-earthis-still-cooling-since-the-minoan-period.html.

Encyclopedia... (1949). Encyclopedia of Ukraine in 2 volumes. Responsible Editors Volodymyr Kubijovyč, Zenon Kuzela. Munich-New York. http://izbornyk.org.ua/encycl/eui025.htm.

Fagan, B. (2008). The Great Warming: Climate Change and the Rise and Fall of Civilizations. New York: Bloomsbury Press.

Gnativ, P. S. (2015). Dynamika landshaftnyh ecosystem ta evoljucija sociumu Pivdenno-Zaxidnoho Podillja uprodovz holocenu [The dynamics of landscape eco- 
systems and evolution of society on Southwestern Podillya during the Holocene] Biological Resources and Nature Management, 7(3-4), 49-57. http://journals.nubip.edu.ua/index.php/Bio/article/vie w/6461 (in Ukrainian).

Grygorenko, O. P., \& Jesjunin, S. M. (2011). Podii ta pamjatky kozackoji doby Xmelnyckoji oblasti. [Events and attractions of Cossack era on Khmelnitsky region] (in Ukrainian)

Gucalo, J. (1996). Mentalnist ordy: Statti. [Mentality horde: Article]. Prosvita. Kyiv (in Ukrainian).

Harenberg, B. (1992). Chronik der Menschheit. Buch. Dortmund, Chronik-Verl.

Hausfather, Z. (2016). Antarctica seen raising global sea level by 2100. Thursday, April 7, 2016. https://www.yaleclimateconnections.org/2016/04/anta rctic-melting-to-boost-sea-levels-by-2100.

Hnativ, P. S. et al. (2012). Pryrodni resursy Ukrainy [Book: The natural resources of Ukraine] Lviv: Kamula (in Ukrainian).

Hnativ, P. S., \& Snintynskyj, V. V. (2017). Ekosystemy i systemnyy analiz [Book: Ecosystems and System Analysis]. Kolir PRO. Lviv (in Ukrainian).

Humilov, L. N. (1968). Etnos i landshaft [Ethnicity and landscape]. http://gumilevica.kulichki.net/articles/Article 91.htm (in Russian).

Jones, P. D., Briffa, K. R., Barnett, T. P., \& Tett, S. F. B. (1998). High-resolution palaeoclimatic records for the last millennium: Interpretation, integration and comparison with control-run temperatures. Holocene, 8, 455-471. doi: 10.1191\%2F095968398667194956.

Migowskia, C., Stein, M., Prasad, S., Negendank, J. F. W., \& Agnon, A. (2006). Holocene climate variability and cultural evolution in the Near East from the Dead Sea sedimentary record. Quaternary Research, 66(3), 421-431. doi: 10.1016/j.yqres.2006.06.010.

Moberg, A., Sonechkin, D. M., Holmgren, K., Datsenko, N. M., \& Karlén, W. (2005) Highly variable northern hemisphere temperatures reconstructed from low-and high-resolution proxy data. Nature, 433(7026), 613617. doi: 10.1038/nature03265.

Oppenheimer, C., Scaillet, B., \& Martin, R. S. (2011). Sulfur Degassing From Volcanoes: Source Conditions, Surveillance, Plume Chemistry and Earth System Impacts. Sulfur in Magmas and Melts: Its Importance for Natural and Technical Processes, 73, 363-421. https://hal-insu.archives-ouvertes.fr/insu00614926/document.

Osborn, T. J. (2004). Simulating the winter North Atlantic Oscillation: the roles of internal variability and greenhouse gas forcing. Climate Dynamics, 22, 605-623. doi: 10.1007/s00382-004-0405-1.

Preiser-Kapeller, J. (2013a). Winter is coming? Climate and medieval history in global perspective. Wien.
https://www.academia.edu/5396163/Winter is comin g Climate and medieval history.

Preiser-Kapeller, J. (2013b). A Climate for Crusades? Weather, climate and armed pilgrimage to the Holy Land (11th-14th Century). Palaeoclimatology. https://www.academia.edu/5411406/A_Climate for Crusades Weather.

Preiser-Kapeller, J. (2014). Archaeobotanical Database in Hungary from the Neolithicto the Modern Age. https://www.researchgate.net/publication/277719021 Archaeobotanical Database in Hungary.

Schaller, M., \& Weigel, H.-J. (2007). Landbauforschung Völkenrode. FAL Agri-cultural Research: Analyse des Sachstands $\mathrm{zu}$ Auswirkungen von Klimaveränderungen auf die deutsche Landwirtschaft und Maßnahmen zur Anpassung. Endredaktion: Stefan Schrader.

Schönwiese, C.-D. (2008). Klimatologie. Ulmer (UTB), 3. Aufl., Stuttgart.

Semenjuk, S. (2010). Istorija ukrainskoho narodu [The history of the Ukrainian people]. Apriory. Lviv (in Ukrainian).

The Journal... (2014). The Journal of William de Rubruquis French man of the order of the minorite friers, unto the East parts of the worlde. An. Dom. 1253 / Last updated Wednesday, December 17, 2014. https://ebooks.adelaide.edu.au/h/hakluyt/voyages/v02/ rubruquis/complete.html.

The Tchortkiv District. (1974). A Collection of Memoirs and Historical Data. Counties: Tchortkiv, Kopychyntti, Borthchlv, Zallshchyky // Editorial staff: Olha Sonevytska, Bohdan Stefanovych Roman Drazhnyovsky. Publisher: Executive Committee of the Tchortkiv District Countrymen Book cover designed by Yakiv Hnizdovsky. New York-Paris-SidneyToronto (in Ukrainian).

Ukraina... (2005). Ukraina: osnovni tendencii vzajemodii suspilstva i pryrody u XX st. (geografichnyy aspect) [Ukraine: main trends of interaction between society and nature in the twentieth century (Geographical aspect)] Kyiv: Akademperiodyka (in Ukrainian)

Veklych, M. F. (1990). Osnovy paloelandshaftovedeniya. Kniga. [Basics of Paleo Landscape. Book] Naukova dumka. Kyiv (in Russian).

Abashyna, N. S. (2003). Velyke pereselennia narodiv. [Great migration of people - electronic resource]. Entsyklopediia istorii Ukrainy. 1(A-V). Naukova dumka. K. https://www.printfriendly.com/p/g/ hWDKkw (in Ukrainian).

Zaliznjak, L. L. (2008). Poxodzennja ukrainciv: miz naukojy ta ideologijeju [Book: Origin of Ukrainian: between science and ideology] Kyiv: Tempora (in Ukrainian) 